\title{
PROFESSIONAL IPHONE ® AND IPAD TM DATABASE APPLICATION PROGRAMMING
}

\section{Iveta ŽOUŽELKOVÁ}

\section{PROFESIONÁLNÍ PROGRAMOVÁNÍ DATABÁZOVÝCH APLIKACÍ PRO IPHONE A IPAD}

(ALESSI, Patrick. Professional iPhone ${ }^{\circledR}$ and iPad ${ }^{\mathrm{TM}}$ - Database Application Programming. Indianapolis : Wiley Publishing Inc., 375 s. ISBN 978-0-470-63617-6)

\section{1 Úvod}

Se stále narůstající uživatelskou oblibou mobilních zařízení iPhone a iPad narůstají také požadavky na aplikace umožňující sofistikovanou správu dat uložených na těchto zařízeních. Především vývojáři potřebují znát nejefektivnější způsoby jak na tato zařízení přenášet data. Klíčový je také způsob jejich dalšího zpracovávání a co nejvhodnější nastavení přenosu dat na externí zařízení.

Tato odborná publikace je určena profesionálům a všem dalším zájemcům, kteří hledali odpovědi právě na tyto důležité otázky související s uvedenými mobilními zařízeními.

Mnohokrát oceněný americký vývojář Patrick Alessi přináší dlouho žádaný komplexní rozbor metodiky práce $\mathrm{s}$ daty na těchto zařízeních $\mathrm{v}$ rámci architektury operačního systému iOS. Ve své analýze jde patřičně do hloubky a zabývá se způsobem zobrazování a manipulací s daty, vytvářením a správou dat užitím frameworku Core Data. $[1,2]$

\section{0 autorovi}

Patrick Alessi již vytvořil řadu aplikací pro správu dat počínaje malými firemními databázemi a velkokapacitními systémy pro United States Air Force konče. Autor této anglicky psané publikace vyvíjí aplikace pro oficiální obchod Apple iTunes, navrhl řadu systémů pracující $\mathrm{v}$ reálném čase, graficky náročných desktopových aplikací a her. [1,3]

Vytvořil jedny z nejlepších placených aplikací pro iPhone MotivationalQuotes, které jsou určeny pro firemní použití. Je také autorem populární aplikace CNotes. [4] Aplikace umožňuje efektivně propojit poznámky a kontakty mezi jednotlivými mobilními zařízeními. [5]

V současnosti se autor věnuje tématu mobility a vývoji graficky náročných aplikací a her pro mobilní zařízení jako právě iPhone nebo iPad. [2]

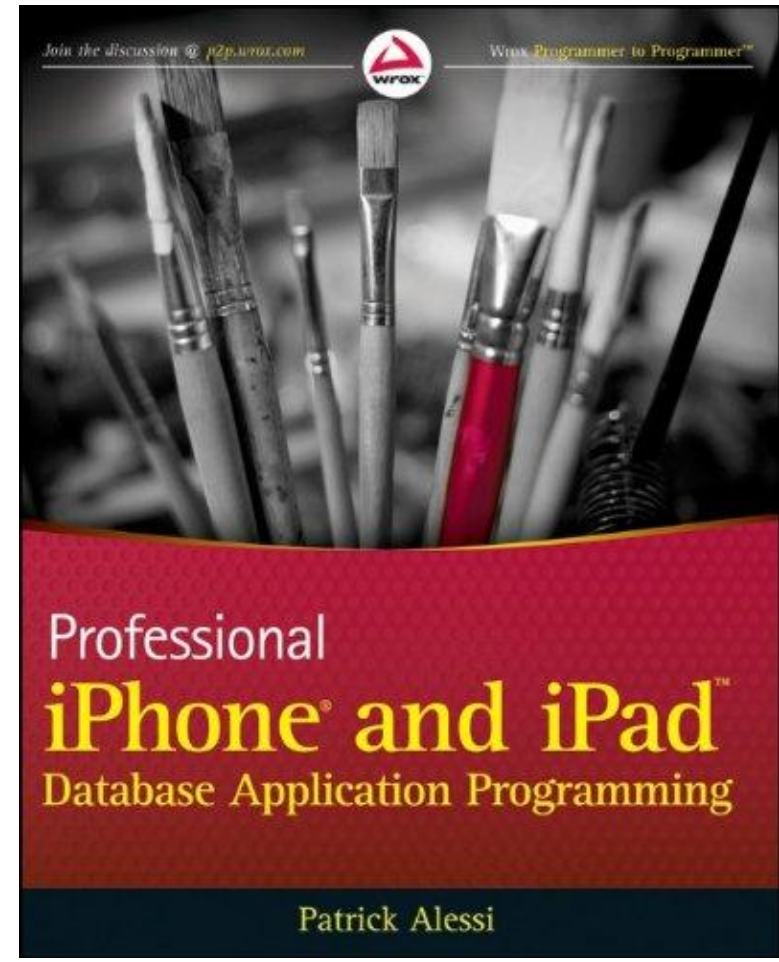

Obr 1: Obálka knihy.

\section{3 Členění a obsah knihy}

Výukový koncept této knihy je velmi názorný. Autor předkládá ukázkový projekt, který společně se čtenářem postupně buduje současně s nárůstem teoretických znalostí načerpaných ze studia této publikace. Následující kapitola tak znalostmi i dovednostmi staví na té předešlé a rozvíjí ji.

Publikace je přehledně rozdělena do 3 hlavních částí, které se skládají z 11 kapitol doplněné apendixem zaměřeným na řešení modelových problémů při vývoji.

První kapitola čtenáře srozumitelně seznámí s integrovaným developerským rozhraním Xcode. Dále popisuje jak vytvořit jednoduchou aplikaci založenou na způsobu zobrazení UITableView. [6] 
Následující kapitola „2 - „iPhone a iPad databáze: SQLite“ znalosti prohlubuje, dále pokračuje ve vývoji modelové aplikace a současně představuje relační databázový systém SQLite. Pokud čtenář není blíže seznámen se SQLite nebo programováním pro UITableView, jsou pro něj zejména první 4 kapitoly knihy velmi prínosné.

Autor věnuje zhruba třetinu knihy (5 kapitol) užívání Core Data včetně základního seznámení s tímto frameworkem. Poslední třetina knihy sestává ze 2 kapitol, které jsou zaměřeny na propojení s webovými službami, což je v souvislosti s aplikacemi určenými pro správu dat velmi užitečné. Škoda, že tak důkladný autor nevěnoval této oblasti více pozornosti (nejefektivnější metody ukládání dat $\mathrm{z}$ webových služeb, jak si co nejlépe poradit se synchronizací atd.). Stejně jako je vhodnějšś si položit otázku který parser XML je pro daný účel nejvhodnější, než hledat odpověd' na otázku, zda externí parser použít. [7]

\section{Závěr}

„Professional iPhone ${ }^{\circledR}$ and iPad TM Database Application Programming “ rozhodně doporučuji nejen zájemcům o efektivní správu dat pro produkty Apple a externí zařízení, ale také profesionálům, kteří navrhují aplikace pro mobilní zařízení v rámci architektury operačního systému iOS.

Hlavní prínos této publikace spočívá $\mathrm{v}$ chytré názornosti postavené na praktických ukázkách v rámci navrhování modelové aplikace za postupného prohlubování znalostí. Tento prístup vytváří nejlepší možný základ pro pochopení dané problematiky. Přehledné členění a precizní návaznost kapitol této knihy představuje komplexního průvodce pro začátečníka i pokročilého. Chytrý způsob členění publikace a kontinuity jednotlivých kapitol však může být i určitou nevýhodou. Zájemci o konkrétní část celého tématu tak budou chybět znalosti $\mathrm{z}$ předchozích kapitol (vzhledem $\mathrm{k}$ úzkému kontextu).

Publikace přináší cennou a ucelenou osvětu ve formě názorného průvodce. Ve stále aktuálnější oblasti mobilních aplikací je odborný rozbor pro zasvěcení do principů fungování práce $\mathrm{s}$ daty klíčovým pomocníkem.

\section{Poděkování}

Článek vznikl za finanční podpory Interní grantové agentury Univerzity Tomáše Bati číslo IGA/FAI/2013/048.

\section{Literatura}

[1] Professional iPhone and iPad - Database Application Programming. 2013 [cit. 2013-0606]. Dostupné z: http://shop.oreilly.com/product 19780470636176.do

[2] Professional iPhone and iPad Database Application Programming

by Patrick Alessi. 2012 [cit. 2013-06-06].

Dostupné z:

http://www.goodreads.com/book/show/9619933professional-iphone-and-ipad-database-

application-programming

[3] Wiley: Beginning iOS Game Development Patrick Alessi. 2011 [cit. 2013-06-06]. Dostupné z: http://eu.wiley.com/WileyCDA/WileyTitle/ productCd-1118107322, descCd-authorInfo.html

[4] Mobile: Professional iPhone and iPad Database Application Programming. 2010 [cit. 2013-06-06]. Dostupné z:

http://www.wrox.com/WileyCDA/WroxTitle/Pro fessional-iPhone-and-iPad-Database-ApplicationProgramming.productCd-0470636173,descCdauthorInfo.html

[5] CNotes Contact Notes. Patrick Alessi. 2013 [cit. 2013-06-06]. Dostupné z:

http://pwalessi1.home.comcast.net/ pwalessi1/C

Notes.html

[6] UITableView Tutorial. cwalcott. 2011 [cit. 2013-06-06]. Dostupné z:

http://www.iosdevnotes.com/2011/10/uitablevie w-tutorial/

[7] iOS Book Reviews: Professional iPhone and iPad Database Application Programming. 2011 [cit. 2013-06-06]. Dostupné z: http://chesstris.com/2011/05/11/ios-bookreviews-professional-iphone-and-ipad-databaseapplication-programming/
Ing. Iveta Žouželková
Univerzita Tomáše Bati ve Zlíně
nám. T. G. Masaryka 5555,
76001 Zlín,
Česká republika
telefon: +420 576035133
E-mail: zouzelkova@fai.utb.cz,
Www pracoviště: www.fai.utb.cz 